\title{
Estuarine immigration by crab postlarvae: mechanisms, reliability and adaptive significance
}

\author{
John H. Christy*, Steven G. Morgan** \\ Smithsonian Tropical Research Institute, Apartado 2072, Balboa, Ancón, Panama \\ or \\ Unit 0948, APO AA 34002-0948, USA
}

\begin{abstract}
Most estuarine crab larvae emigrate from estuaries soon after they hatch, develop to the postlarval stage in the coastal ocean and then immigrate to estuaries and settle in adult habitats. We studied the patterns and mechanisms of immigration by postlarvae of $9 \mathrm{crab}$ taxa in the small, highsalinity North Inlet estuary (South Carolina, USA) by sampling the plankton daily for $32 \mathrm{~d}$ over the length of the estuary. A concurrent study of larval production and flux showed that all taxa rapidly emigrate, thereby establishing empirically the importance of immigration in this estuary and giving us the rare opportunity to compare the relative species abundance of emigrating larvae and immigrating postlarvae. Contrary to the popular view that planktonic development in the sea uncouples larval recruitment from production, the community composition of emigrants and immigrants were comparable. Postlarvae immigrated at night and primarily on large amplitude flood tides. We show that this pattern is common in other estuaries and we argue that it reduces fish predation on immigrating postlarvae. Saltatory, up-estuary immigration was evident in 5 species that moved from the lower to the upper estuary $(4 \mathrm{~km})$ in 1 to $3 \mathrm{~d}$. Although immigration rates have not been measured directly in other estuaries, a study of postlarval settlement in Mobile Bay suggests that rates may vary geographically in relation to variation in the tidal regime.
\end{abstract}

KEY WORDS: Larval migration - Crab postlarvae Estuary Nocturnal flood tide immigration

\section{INTRODUCTION}

The planktonic larvae of many estuarine invertebrates often may be retained in estuaries (Christy \& Stancyk 1982, Stancyk \& Feller 1986) and contribute importantly to adult populations (Gaines \& Bertness 1992). However, the larvae of estuarine crabs rapidly disperse seaward, away from adult populations. Except in large estuaries, most species (but see Cronin 1982, Cronin \& Forward 1982) seldom remain in their estuary of origin throughout development (reviewed by Epifanio 1988, McConaugha 1988). Seaward dispersal of crab larvae, often into the coastal ocean, is sufficiently common to suggest it is not incidental loss or 'leakage' from an otherwise retained estuarine larval pool. Rather, the timing of larval release, typically

-E-mail: christyj@naos.si.edu

- Present address: Marine Sciences Research Center, State University of New York, Stony Brook, New York 11794 5000, USA on large amplitude, nocturnal ebb tides (reviewed by Morgan 1995a, Morgan \& Christy 1995), and behavioral mechanisms that position larvae in ebb-directed currents (e.g. Sulkin 1984, Zeng \& Naylor 1996a) specifically promote rapid seaward transport of larvae (Christy 1982, Christy \& Stancyk 1982, Lambert \& Epifanio 1982, Provenzano et al. 1983, Brookins \& Epifanio 1985, Salmon et al. 1986, Epifanio et al. 1988, Dittel et al. 1991, Lago 1993, Queiroga et al. 1994), not their retention. Substantial comparative (Morgan \& Christy 1994, 1995) and experimental (Morgan 1987, 1989, 1990, Morgan \& Christy 1996a, b, Hovel \& Morgan 1997 ) evidence strongly suggests that the timing of larval release by crabs, which is the last act of maternal care, is selected by predation, primarily by planktivorous fish on larvae. Rapid seaward dispersal of crab larvae soon after their release may be the first leg of a true migration (Strathmann 1982) that increases larval survival by reducing predation rates (Christy 1982, Morgan 1987, 1990, 1995a, Morgan \& Christy 1995, Hovel \& Morgan 1997). 
In coastal and shelf waters, the later larval stages (zoeae) and the postlarvae (megalopae) of estuarine crabs show marked interspecific differences in their vertical distribution in the water column and their extent of dispersal from the shore (e.g. Sandifer 1973, 1975, Johnson 1985, McConaugha 1988). Hence, the relative importance of the physical processes that may transport postlarvae to locations near the entrances of estuaries also varies interspecifically. For example, wind-driven currents often may bring surfacedwelling blue crab Callinectes sapidus postlarvae from shelf waters to the lower estuary (Johnson 1985 . Goodrich et al. 1989, Johnson \& Hester 1989, Olmi 1995, Morgan et al. 1996, Garvine et al. 1997), while deep, on-shore, residual currents may affect landward transport of bottom-dwelling postlarvae of fiddler (Epifanio et al. 1988) and some xanthid crabs (Johnson 1985). Regardless of the processes that bring postlarvae to the entrances of estuaries (Shanks 1995, 1998, Eckman 1996), they must then move up-stream to adult habitats to settle.

Here we describe spatial and temporal patterns of crab postlarval immigration in North Inlet estuary, South Carolina (USA). A previous study showed that fiddler crab (Uca spp.) postlarvae were most abundant in the water column in the upper North Inlet estuary during nocturnal flood tides. This led to the hypothesis that postlarvae may move in an episodic, saltatorial fashion on sequential nocturnal flood tides to adult habitats (Christy 1982). In other estuaries, Uca spp. and most other estuarine crab postlarvae also usually are more abundant on flooding tides at night than at other times (see 'Discussion'). Perhaps because this pattern is common, saltatory, up-estuary postlarval immigration on nocturnal flood tides frequently has been incorporated into conceptual models of the dispersal ecology of estuarine crab larvae (e.g. Epifanio et al. 1984, Little \& Epifanio 1991, DeVries et al. 1994, Olmi 1995, Tankersely et al. 1995). However, the distance, rate and daily pattern of movement of postlarvae from the mouth to the upper estuary depends on several factors, including their distribution relative to oscillating tidal currents (DeVries et al. 1994), competence to settle when inside the estuary (Lipcius et al. 1990, Metcalf \& Lipcius 1992, Morgan et al. 1996, Zeng \& Naylor $1996 \mathrm{~b})$, the probability of encountering suitable habitats along the estuarine gradient (Morgan et al. 1996) and predation. Therefore, potential and realized immigration rates and spatial patterns may differ, making it important to measure immigration directly. To date, immigration patterns have been inferred from either the vertical distributions of postlarvae in the water column or temporal settlement patterns (e.g. Lipcius et al 1990, Olmi et al. 1990). To demonstrate saltatory, up estuary immigration of postlarvae on nocturnal flood tides it is necessary to show not only that postlarvae are abundant in the water column during nocturnal flood tides and rare at other times, but also that peaks in their abundance in the water column move progressively, on subsequent nights and flood tides, from the lower to the upper estuary.

This study had 4 objectives. First, we sought direct evidence of progressive, up-estuary immigration of crab postlarvae by monitoring for a month postlarval abundance in the plankton during each nocturnal flood tide at stations in the lower, mid and upper estuary. To verify that postlarvae move primarily upstream and at night, plankton samples also were taken during daytime flood and nighttime ebb tides. To our knowledge, this is the only direct test of Christy's (1982) hypothesis of saltatory, upstream immigration by postlarvae.

Second, we tested for a positive correlation between the intensity of immigration and the amplitude of the nocturnal flood tide during the biweekly tidal amplitude cycle. Other studies, primarily of blue crab Callinectes sapidus postlarvae, have detected such a correlation at some sites and times (van Montfrans et al. 1990, 1995, Boylan \& Wenner 1993, Metcalf et al. 1995, Olmi 1995, Morgan et al. 1996). To determine whether this pattern is general, we tested for a non-random association between the postlarval abundance of $C$. sapidus and 3 other species and nocturnal flood tide amplitude.

Third, we evaluated the widely held view that planktonic processes uncouple larval settlement from production (Caley et al. 1996). A concurrent study at North Inlet showed that newly hatched crab Iarvae of all common species in this estuary emigrate rapidly to the coastal ocean (Christy 1982, Christy \& Stancyk 1982). This observation not only established empirically the importance of postlarval immigration to North Inlet, it gave us the rare opportunity (see also Dittel et al. 1991, Hovel \& Morgan 1997) to compare the relative abundance of emigrating larvae and immigrating postlarvae for a full and diverse assemblage of estuarine brachyuran crabs. Finally, we comment on the possible adaptive significance of postlarval immigration on rocturnal flood tides.

\section{MATERIALS AND METHODS}

Study site and tidal patterns. North Inlet estuary, South Carolina, USA $\left(33^{\circ} 22^{\prime} \mathrm{N}, 79^{\circ} 10^{\prime} \mathrm{W}\right.$, Fig. 1) is a small $\left(32.3 \mathrm{~km}^{2}\right)$, shallow $(<3 \mathrm{~m}$ depth except in the inlet mouth), high-salinity ( 34 to 35 psu), well-mixed estuary in which the average tidal range is $1.4 \mathrm{~m}$ and the currents are dominated by the semidiurnal partial tide (Kjerfve \& Proehl 1979, Palmer et al. 1980, Kjerfve 
Fig. 1. Northern part of the North Inlet estuary, South Carolina, USA. (-) Stations in the lower, mid and upper estuary where crab postlarvae were collected; $(\star)$ upper-estuary station where newly hatched crab larvae and Uca spp. postlarvae were collected in related studies. Inlet morphology is approximate

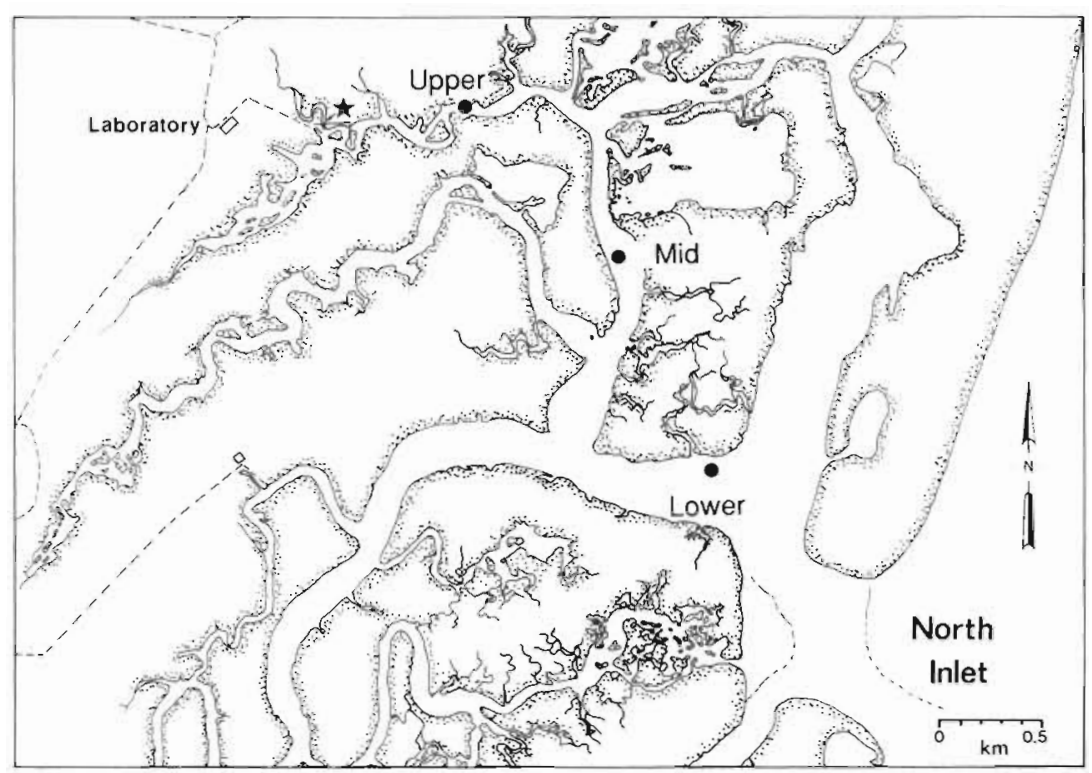

et al. 1982). In tidal creeks, flood flow typically is maximum about $1.5 \mathrm{~h}$ after the mid-flood tidal stage (Kjerfve \& Proehl 1979, Kjerve \& Wolaver 1988), a common pattern in tidal channels with intertidal bank crests (Pethick 1980).

The semidiurnal tidal pattern at North Inlet (2 high and low tides every $24.8 \mathrm{~h}$, on average) occurs on the entire Atlantic coast of the USA and it is the most common one world-wide (Barnwell 1976). Here we review features of this tidal regime (Fig. 2) that pertain to immigration by crab postlarvae. We define flood tide amplitude as the difference in water level between a slack low and the next slack high tide (the tidal range). The amplitudes of the 2 semidiurnal flood tides usually are unequal, with the largest difference every 13 to $14 \mathrm{~d}$ when the moon is farthest north and south of the earth's equator in its $27.3 \mathrm{~d}$ declination cycle. We define a 'nocturnal' flood tide as one that is slack high after sunset and before sunrise. If both high tides are slack high during daylight, then the nocturnal flood tide is the one that is slack high nearest the time of sunset or sunrise. The amplitudes of the nocturnal flood tides cycle with a longterm, average biweekly period of $14.8 \mathrm{~d}$, half the 29.5 d lunar synodic month. However, this period is bimodally distributed, varies from about 12 to $17 \mathrm{~d}$ (as it did during this study; Fig. 2), and alternates between shorter and longer periods. The largest amplitude nocturnal flood tides in a biweekly cycle fall on or after (depending, in part, on day length) the dates of the spring tides, which may precede or follow the full and new moons (syzygies) by one to several days. On the Atlantic coast of the USA, these tides usually peak in the evening so that most of their flood period occurs before sunset. Lower amplitude nocturnal flood tides occur near the time of the neap tides and the first and last quarter moons (quadratures). They are slack high after midnight and flood entirely during darkness. Finally, variation in the distance of the moon from the earth affects the amplitude of the tides. As it is not known whether this $27.6 \mathrm{~d}$ cycle affects postlarval immigration, it will not be discussed.

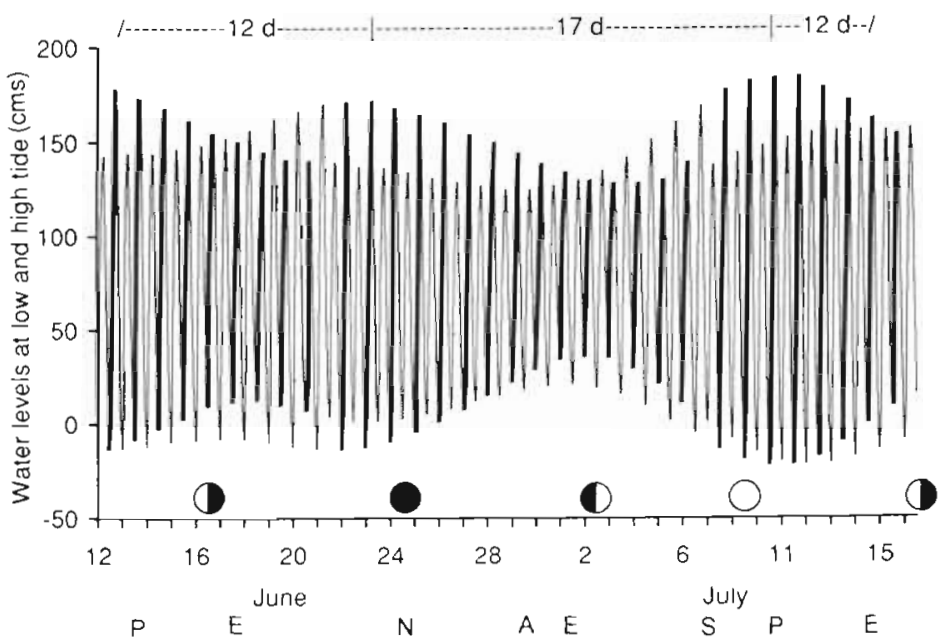

Fig. 2. Water levels at high and low tide in the North Inlet estuary during this study. Heavy lines: amplitudes (tidal ranges) of the nocturnal flood tides, which cycled with alternating 12 and 17 d periods; (O): new moon; (O) full moon; $(O, O)$ quarter moons; $N$ and $S$ : northern- and southern-most declination of the moon; $E$ : moon over the equator $; A$ and $P$ : moon at apogee and perigee. Tick marks on the $x$-axis delimit lunar days, beginning at the time of the first low tide on 12 June. Date (solar day) labels are approximate 
The crab fauna. Newly hatched brachyuran crab larvae were collected nightly (18 May to 10 October, 1979) at a single station in the upper estuary at North Inlet (Christy \& Stancyk 1982; Fig. 1). Fourteen taxa (at least 16 species) were present. The ocypodid fiddler crabs Uca spp. (including $U$. pugilator, $U$. pugnax and U. $\operatorname{minax}$ ) dominated (94\%) the fauna. Other common species, in descending rank of larval abundance, were the grapsids Sesarma cinereum and S. reticulatum, the xanthid Panopeus herbstii, and the pinnotherid Pinnixa chaetopterana. Each of these 5 taxa showed biweekly peaks of larval production on large amplitude, nocturnal ebb tides and all were exported as first stage zoeae to coastal waters (Christy \& Stancyk 1982). Hence, immigration is a necessary phase of larval life for crabs in the North Inlet estuary.

Plankton sampling. From 12 June to 16 July, 1979, the plankton was sampled for crab postlarvae at stations in the mid and upper estuary. Samples also were taken at a third station in the mouth of the inlet on 12 to 13 June 1 nocturnal flood and subsequent nocturnal ebb tide). Due to unsafe conditions, this station was abandoned on 13 June, and a new, lower estuary station was established on 22 June, about $1 \mathrm{~km}$ inside the inlet (Fig, 1). By creek bed, the upper station was approximately $5 \mathrm{~km}$ from the mouth of the estuary and $4 \mathrm{~km}$ from the lower station. Cross-sectional depth profiles near the lower and mid estuary stations show a 2 channel structure (Kjerfve 1978): a deeper channel in which net ebb flow typically dominates, and a shallower channel that usually experiences net flood flow (Kjerfve 1978, Kjerfve \& Proehl 1979). At both the lower and mid estuary stations, the plankton was sampled in the shallower, flood-dominated channel. The upper estuary station was positioned approximately in the middle of the single, shallow channel in this creek. Samples were taken daily except for 20 and 23 June and 5 July.

Plankton was collected from an anchored skiff with a $0.5 \mathrm{~m}$ diameter, $2.5 \mathrm{~m}$ long conical net of $505 \mu \mathrm{m}$ mesh Nitex cloth. The bottom half of the net ring was weighted with chain. An asymmetrical bridle and a slightly buoyant cod-end jar ensured that the plane of the net opening remained approximately vertical and normal to the tidal current. For each collection, the net was lowered to just above the bottom, then raised slowly so that its rim was just under the surface. The net spent about $1 \mathrm{~min}$ at the bottom, ascending, and top positions ( $3.25 \mathrm{~min}$ total sampling time per sample). A calibrated, General Oceanics flow meter with low speed rotor was suspended in the center of the net opening. The volume of water filtered per collection. averaged $20.42 \pm 7.269$ (SD) $\mathrm{m}^{3}(\mathrm{n}=100)$. The plankton was fixed and stored in $4 \%$ buffered formaldehyde solution and lightly stained with Rose Bengal.
All brachyuran postlarvae in each sample were counted and identified, to species when possible, using published descriptions and personal notes from studies of larval development. The postlarvae of the 3 species of fiddler crabs were identified to the genus level. An abundant, previously undescribed postlarva was discovered in the samples. A subsequent study (S.G.M. unpubl.) showed it to be Sesarma reticulatum and that the description of this postlarva by Costlow \& Bookhout (1962) is incorrect. Descriptions of the postlarvae of the Pinnixa species that could have been present are incomplete. However, first stage zoeae of $P$. chaetopterana were abundant on nocturnal ebb tides (Christy \& Stanczyk 1982) and adults of this species are common in the estuary (Grove \& Woodin 1996). Hence, the single morphological type of pinnixid postlarva present in these samples probably is this species. Only 12 Pinnotheres ostreum postlarvae were collected, but first stage crabs, which are the settling stage of this commensal, typically with Crassostrea virginica (Christensen \& McDermott 1958), were abundant. We therefore combined the counts of the postlarvae and first stage crabs of $P$. ostreum.

Immigration patterns. Plankton was collected daily during nocturnal flood tides at the lower, mid and upper stations at, respectively, $3.9 \pm 0.50$ (SD) h ( $\mathrm{n}=$ $22), 4.3 \pm 0.50 h(n=28)$ and $4.6 \pm 0.55 h(n=29)$ after slack low water. This period should have included the peak flood flow. Friedman's 2-way analysis of variance by ranks (blocking on days) was used to detect, for each species, differences in postlarval abundance between the 3 stations.

To determine whether postlarvae are less abundant on nocturnal ebb compared to the preceding nocturnal flood tides, plankton samples were taken at all 3 stations (13 June), and at the mid and upper stations (14 to 16 June) during the early morning nocturnal ebb tides. These collections were made at $1.8 \pm 0.35 \mathrm{~h}(\mathrm{n}=9)$ before low water, when ebb discharge values are high but declining. On 9 to 15 July, the 2 semidiurnal flood tides advanced through sunset and sunrise and their amplitudes differed (evening to morning) from about 0.4 to $-0.2 \mathrm{~m}$. To determine how postlarval densities vary on sequential flood tides that differ in amplitude and proportion of their flood during darkness, collections were made during both floods on these days. Wilcoxon's signed-ranks tests were used to detect significant differences in postlarval abundance for these pair-wise comparisons.

We used cross-correlation analysis to detect progressive movement of postlarvae from the lower to the upper estuary. Correlations were calculated between the daily values of postlarval density at the lower and mid, the mid and upper, and the lower and upper stations. Significant positive correlations at positive Iags 
would indicate progressive, up-estuary movement. For the 3 days collections were missed, we estimated postlarval densities as the mean of 2 values: (1) the average density of the 2 previous and 1 following day and (2) the average density of the 1 previous and 2 following days.

We also used cross-correlation analysis to detect a possible relationship between nocturnal flood tide amplitude and immigration. Correlations were calculated between the 32 daily values of nocturnal flood tide amplitude, and postlarval density (3-station average) for each species. Our objective was to detect possible positive correlations between nocturnal flood tide amplitude and postlarval abundance, not to infer cycles of immigration. We chose not to infer cycles of immigration for 3 reasons: First, our $32 \mathrm{~d}$ series covered only 2.5 tidal amplitude cycles. Second, tidal amplitude cycles of immigration are most likely if the concentration of postlarvae in coastal ocean near the mouth of the estuary either is nearly constant or cycles in phase with the tidal amplitude cycle. Given variation in the intensity of larval production and in the physical processes that affect larval dispersal offshore and delivery onshore (Shanks 1998), neither condition seems probable (but see Shanks 1995). Finally, longterm temporal patterns of settlement, which indirectly document immigration, more often are episodic than cyclic. The computer program SYSTAT (DOS ver. 6.0, SYSTAT, Inc.) was used for this analysis. The times and heights of high and low tide were taken from the NOAA tide tables.

Immigration in other estuaries. For some species in North Inlet, nocturnal flood tide amplitude and postlarval abundance were significantly and positively correlated. A correlation between postlarval abundance and the lunar cycle has been noted occasionally in other studies (e.g. van Montfrans et al. 1990, 1995, Boylan \& Wenner 1993, Olmi 1995), but the correlation between immigration and the more complex nocturnal flood tide amplitude cycle has seldom been specifically addressed (Metcalf et al. 1995). To determine if this is a general pattern, we examined the relationship between postlarval abundance and the approximately biweekly variation in nocturnal flood tide amplitude in other estuaries. We surveyed the literature for data on postlarval abundance that (1) were published as large scale graphs (from which we could accurately read dates) of continuous daily records, at least $15 \mathrm{~d}$ long, which (2) showed at least the presence of postlarvae throughout, and (3) included at least 1 'immigration event,' which we defined qualitatively as a period (days) during which postlarvae were substantially more abundant than during preceding and following periods of similar length. Multiple, short-term (usually daily), large increases and decreases in abundance were ignored as were small amplitude, several-day increases. We included studies that measured immigration either directly, as the density of individuals in the water column during flood tides, or indirectly, as the daily number of individuals on synthetic fiber collectors. On the scale of a several-day immigration event, the planktonic abundance of postlarvae and their abundance on collectors generally are positively correlated (Lipcius et al. 1990, Olmi et al. 1990, O'Connor 1993).

To determine whether immigration events are nonrandomly associated with larger amplitude nocturnal flood tides, we divided the approximately biweekly tidal amplitude cycle during which each immigration event occurred into two, 7 to $8 \mathrm{~d}$ periods, one with larger and the other with smaller amplitude nocturnal flood tides. Tidal amplitudes for the various study sites and dates were obtained from the computer program Tides and Currents (Nautical Software, Inc.). Immigration events were assigned to 1 of these 2 periods. If an event spanned both periods, it was assigned to the one during which more postlarvae were collected. If postlarval abundance and nocturnal flood tide amplitude are not associated, then one would expect equal relative frequencies $(0.5)$ of immigration events during each half of the tidal amplitude cycle (one with larger, the other with smaller amplitude tides). We used the log-likelihood ratio goodness-of-fit test ( $G$-test with William's correction; Sokal \& Rohlf 1981) to test this null hypothesis. Again, for the reasons previously discussed, we did not draw conclusions from this analysis about cycles of immigration. Rather, we asked, given that immigrating postlarvae are present during a biweekly period, do more immigrate on days with larger amplitude flood tides?

\section{RESULTS}

\section{General abundance}

Eight taxa (at least 11 species) of crab postlarvae were collected (Table 1). Uca spp. (3 species), the xanthids, Panopeus herbstii and Eurypanopeus depressus, the grapsids, Sesarma reticulatum and $S$. cinereum, and the pinnotherid Pinnotheres ostreum were sufficiently abundant for more detailed analysis. Postlarvae of these 6 taxa were present in 77 to $99 \%$ of the samples. Except for $S$. reticulatum, which were more abundant at the lower station, there were no significant differences within species in the rank abundance of postlarvae collected daily at the 3 estuarine locations. This is consistent with movement of postlarvae without substantial mortality or settlement from the lower to the upper estuary. 
Table 1. Abundance of brachyuran postlarvae in the North Inlet estuary, South Carolina, USA, 12 June to 16 July, 1979 . Occurrence: number and percentage of all samples at the lower $(n=30)$, mid $(n=39)$ and upper $(n=40)$ stations that contained postlarvae. Mean density calculated for flood tide collections only. Friedman's tests are for significant differences in within-species rank abundance between stations, blocked on collection day, flood tide samples only; test not applied to species with relative abundance $<1 \%$

\begin{tabular}{|c|c|c|c|c|c|c|c|c|}
\hline Species & Station & $\begin{array}{c}\text { Occu } \\
\mathrm{n}\end{array}$ & $\begin{array}{l}\text { ence } \\
\%\end{array}$ & $\begin{array}{c}\text { Absolute } \\
\text { abundance }\end{array}$ & $\begin{array}{c}\text { Relative } \\
\text { abundance (\%) }\end{array}$ & $\begin{array}{l}\text { Mean density } \\
\qquad\left(\mathrm{m}^{-3}\right)\end{array}$ & $\begin{array}{c}\text { Friedman's } \\
\chi^{2}\end{array}$ & $\mathrm{p}$ \\
\hline Uca spp. & $\begin{array}{l}\text { Lower } \\
\text { Mid } \\
\text { Upper } \\
\text { Overall }\end{array}$ & $\begin{array}{r}30 \\
39 \\
39 \\
108\end{array}$ & $\begin{array}{r}100 \\
100 \\
98 \\
99\end{array}$ & $\begin{array}{r}8276 \\
9616 \\
11294 \\
29186\end{array}$ & $\begin{array}{l}81.6 \\
87.2 \\
84.4 \\
84.5\end{array}$ & $\begin{array}{l}12.9 \pm 2.39 \\
17.9 \pm 3.38 \\
13.4 \pm 3.34 \\
14.8 \pm 2.82\end{array}$ & 1.909 & 0.385 \\
\hline Panopeus herbstii & $\begin{array}{l}\text { Lower } \\
\text { Mid } \\
\text { Upper } \\
\text { Overall }\end{array}$ & $\begin{array}{l}27 \\
31 \\
26 \\
84\end{array}$ & $\begin{array}{l}90 \\
80 \\
65 \\
77\end{array}$ & $\begin{array}{r}493 \\
251 \\
429 \\
1173\end{array}$ & $\begin{array}{l}4.9 \\
2.3 \\
3.2 \\
3.4\end{array}$ & $\begin{array}{l}1.2 \pm 0.37 \\
0.5 \pm 0.11 \\
0.4 \pm 0.12 \\
0.7 \pm 0.20\end{array}$ & 1.143 & 0.565 \\
\hline Sesarma reticulatum & $\begin{array}{l}\text { Lower } \\
\text { Mid } \\
\text { Upper } \\
\text { Overall }\end{array}$ & $\begin{array}{l}27 \\
36 \\
34 \\
97\end{array}$ & $\begin{array}{l}90 \\
92 \\
85 \\
89\end{array}$ & $\begin{array}{r}489 \\
268 \\
332 \\
1089\end{array}$ & $\begin{array}{l}4.8 \\
2.4 \\
2.5 \\
3.2\end{array}$ & $\begin{array}{l}1.1 \pm 0.28 \\
0.6 \pm 0.11 \\
0.4 \pm 0.08\end{array}$ & 16.881 & $<0.001$ \\
\hline Sesarma cinereum & $\begin{array}{l}\text { Lower } \\
\text { Mid } \\
\text { Upper } \\
\text { Overall }\end{array}$ & $\begin{array}{l}27 \\
35 \\
36 \\
98\end{array}$ & $\begin{array}{l}90 \\
90 \\
90 \\
89\end{array}$ & $\begin{array}{l}331 \\
275 \\
361 \\
967\end{array}$ & $\begin{array}{l}3.3 \\
2.5 \\
2.7 \\
2.8\end{array}$ & $\begin{array}{l}0.7 \pm 0.62 \\
0.4 \pm 0.06 \\
0.4 \pm 0.07 \\
0.5 \pm 0.25\end{array}$ & 4.159 & 0.125 \\
\hline Pinnotheres ostreum & $\begin{array}{l}\text { Lower } \\
\text { Mid } \\
\text { Upper } \\
\text { Overall }\end{array}$ & $\begin{array}{l}28 \\
33 \\
38 \\
99\end{array}$ & $\begin{array}{l}93 \\
85 \\
95 \\
91\end{array}$ & $\begin{array}{l}251 \\
289 \\
267 \\
807\end{array}$ & $\begin{array}{l}2.5 \\
2.6 \\
2.0 \\
2.3\end{array}$ & $\begin{array}{l}0.5 \pm 0.75 \\
0.6 \pm 1.01 \\
0.4 \pm 0.35 \\
0.5 \pm 0.70\end{array}$ & 0.643 & 0.725 \\
\hline Eurypanopeus depressus & $\begin{array}{l}\text { Lower } \\
\text { Mid } \\
\text { Upper } \\
\text { Overall }\end{array}$ & $\begin{array}{l}26 \\
30 \\
31 \\
87\end{array}$ & $\begin{array}{l}87 \\
77 \\
78 \\
80\end{array}$ & $\begin{array}{l}110 \\
144 \\
278 \\
532\end{array}$ & $\begin{array}{l}1.1 \\
1.3 \\
2.1 \\
1.5\end{array}$ & $\begin{array}{l}0.2 \pm 0.07 \\
0.3 \pm 0.07 \\
0.3 \pm 0.08 \\
0.3 \pm 0.04\end{array}$ & 1.738 & 0.419 \\
\hline Pinnixa spp. & $\begin{array}{l}\text { Lower } \\
\text { Mid } \\
\text { Upper } \\
\text { Overall }\end{array}$ & $\begin{array}{l}15 \\
20 \\
27 \\
62\end{array}$ & $\begin{array}{l}50 \\
51 \\
68 \\
57\end{array}$ & $\begin{array}{r}70 \\
56 \\
290 \\
416\end{array}$ & $\begin{array}{l}0.7 \\
0.5 \\
2.2 \\
1.2\end{array}$ & $\begin{array}{l}0.2 \pm 0.26 \\
0.1 \pm 0.12 \\
0.2 \pm 0.22 \\
0.2 \pm 0.20\end{array}$ & 1.825 & 0.402 \\
\hline Callinectes sapidus & $\begin{array}{l}\text { Lower } \\
\text { Mid } \\
\text { Upper } \\
\text { Overall }\end{array}$ & $\begin{array}{l}12 \\
19 \\
22 \\
53\end{array}$ & $\begin{array}{l}40 \\
49 \\
55 \\
49\end{array}$ & $\begin{array}{r}84 \\
98 \\
110 \\
292\end{array}$ & $\begin{array}{l}0.8 \\
0.9 \\
0.8 \\
0.9\end{array}$ & & & \\
\hline Dispanopeus sayi & $\begin{array}{l}\text { Lower } \\
\text { Mid } \\
\text { Upper } \\
\text { Overall }\end{array}$ & $\begin{array}{l}16 \\
16 \\
13 \\
45\end{array}$ & $\begin{array}{l}53 \\
41 \\
33 \\
41\end{array}$ & $\begin{array}{l}37 \\
28 \\
21 \\
86\end{array}$ & $\begin{array}{l}0.4 \\
0.3 \\
0.2 \\
0.3\end{array}$ & & & \\
\hline
\end{tabular}

\section{Flood-ebb contrasts}

Comparison of the densities of 6 taxa that were collected on 4 nocturnal flood tides, and the immediately following nocturnal ebb tides, at 3 (June 12 to 13) or 2 (June 13 to 16 ) stations, showed that all species were significantly more abundant during the nocturnal flood (Fig. 3, Wilcoxon's Signed Rank tests, $\mathrm{p}<0.001$ for Pinnotheres ostreum, $\mathrm{p}<0.005$ for all other species). At the Iower and mid estuary stations all samples were collected from the flood dominated channel. To determine if this biased our results, we compared the percent reduction in postlarval density per species and flood-ebb tide pair at the upper station (single channel) and the mid estuary station ( 2 channels). Percent reductions in density were not significantly greater for samples taken in the flood dominated channel in the mid estuary (Sign test, $n=20,9$ cases with percent density reduction greater at the mid estuary station, $\mathrm{p} \geqslant 0.05$ ).

\section{Semidiurnal flood tide contrasts}

From 9 to 15 July, postlarvae were collected during the late afternoon to early evening flood tides and the following early to mid morning flood tides. The maxi- 
mum amplitude nocturnal flood tide was slack high at 20:37 h on 10 July. Except for the final day in this collection series, the amplitude of the evening flood tide was greater than the amplitude of the morning flood tide. As the times of the 2 semidiurnal high tides advanced daily, the percentages of the flood tide during darkness gradually increased for the evening flood and decreased for the morning flood tide (Table 2).

Postlarvae of all 5 taxa were not significantly more abundant on the larger amplitude semidiurnal flood tide (Wilcoxon's Signed Ranks tests, $p=0.05$ for Sesarma reticulatum, $p>$ 0.05 for the other species). In contrast, postlarval densities of all species but Pinnotheres ostreum ( $\mathrm{p}>0.05$ ) were significantly greater in the collections made on the tide with the greater percentage of its flood period during darkness (the more 'nocturnal' semidiurnal flood tide, first in the morning,

then in the evening; Uca spp. and $S$. reticulatum, $\mathrm{p}<$ $0.005 ; S$ cinereum and Panopeus herbstii, $\mathrm{p}<0.025$; Eurypanopeus depressus, $\mathrm{p}<0.05$ ). Three of these

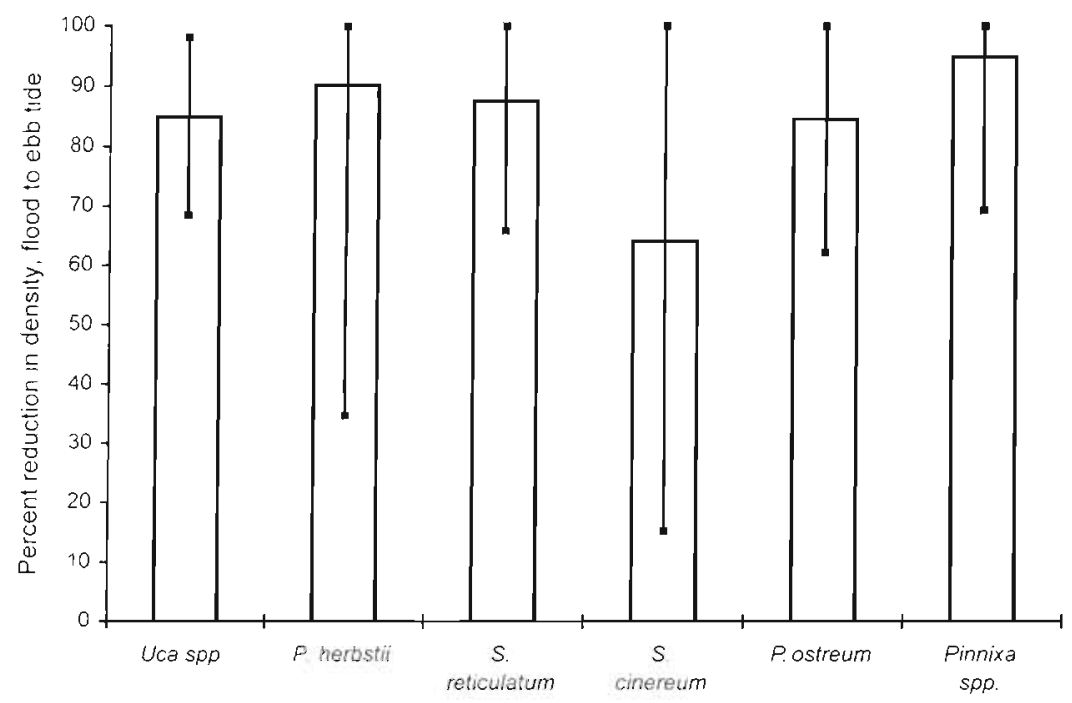

Fig. 3. Uca spp., Panopeus herbstiu, Sesarma reticulatum, Sesarma cinereum, Pinnotheres ostreum and Pinnixa spp. Percent reduction in postlarval density on nocturnal ebb tides compared to their density on the preceding nocturnal flood tides. Bars: means of 9 flood-ebb tide pairs, at 3 (June 12 to 13) or 2 (June 13 to 16) stations; vertical lines: range. Percent density reduction $=[($ flood density ebb density)/ flood density] $\times 100$

tides were smaller, and 3 greater in amplitude than the preceding or following flood tide with which they were paired

Table 2. Differences between consecutive evening and morning flood tides (from July 9 to 15,1979 ) in amplitude, percentage of the flood during darkness and the densities $\left(\mathrm{m}^{-3}\right)$ of postlarvae

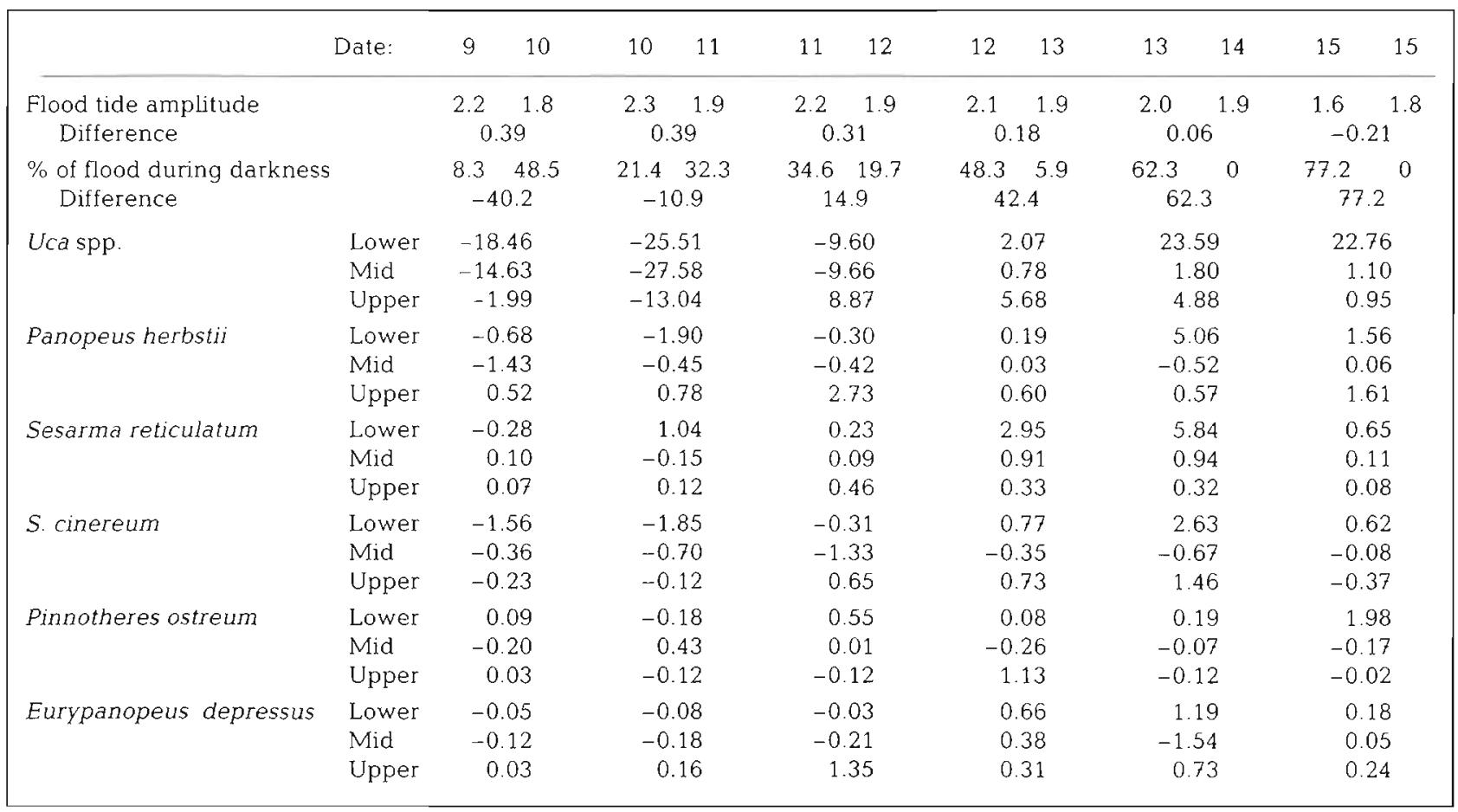



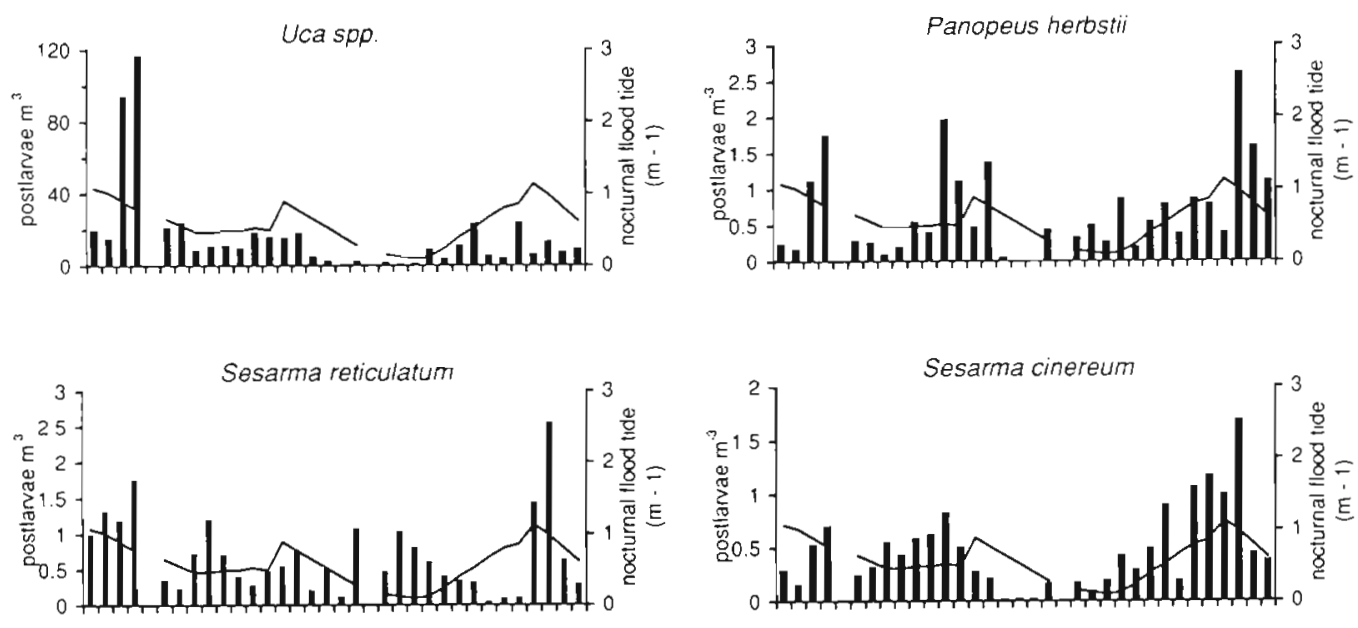

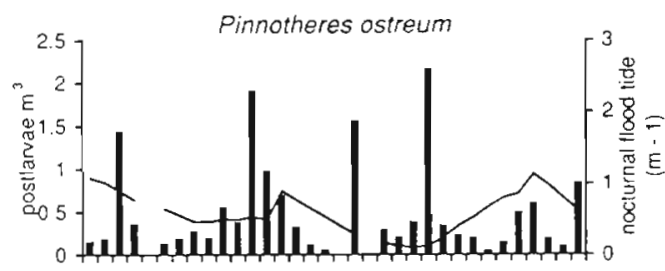

June 12 - July 15,1979

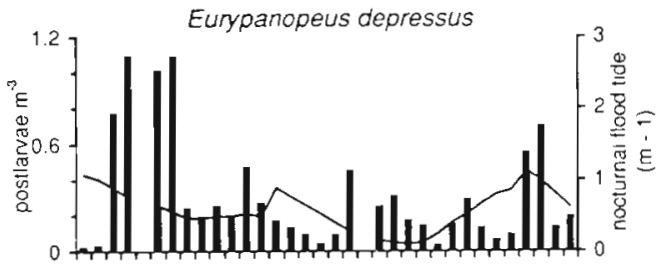

June 12 - July 15,1979

Fig. 4. Uca spp., Panopeus herbstii, Sesarma reticulatum, Sesarma cinereum, Pinnotheres ostreum and Eurypanopeus depressus. Daily variation in the concentration of crab postlarvae in the plankton $\left(\mathrm{m}^{-3}\right)$ during nocturnal flood tides, $12 \mathrm{June}$ to $15 \mathrm{July}, 1979$, North Inlet estuary. Vertical bars: 2 - or 3-station average densities; line: amplitude of the nocturnal flood tide ( $1 \mathrm{~m}$ for scale)

\section{Postlarval abundance and nocturnal flood tide amplitude}

During the $32 \mathrm{~d}$ sampling period, there were 3 maxima in nocturnal flood tide amplitude (Figs. 1 \& 4). Visual inspection of the daily values of postlarval densities (averaged across stations) indicated, for some species, possible positive correlations at positive lags between nocturnal flood tide amplitude and postlarval abundance (Fig. 4). Cross-correlations were significant and positive at lags of 1 to $3 \mathrm{~d}$ for Uca spp., Panopeus herbstii, Sesarma reticulatum and Eurypanopeus de- pressus (Table 3 ). S. cinereum postlarvae were most abundant about $2 \mathrm{~d}$ before the largest amplitude nocturnal floods (approximately on the days of the spring tides) while the postlarval abundance of Pinnotheres ostreum was not correlated with nocturnal flood tide amplitude.

In other estuaries, Uca spp., Dyspanopeus sayi and Callinectes sapidus postlarvae immigrated significantly more often than one would expect by chance during the half of the biweekly cycle with larger amplitude nocturnal flood tides (Uca spp.: $G=6.532$, p < $0.025, D$. sayi: $G=18.739, \mathrm{p}<0.001, C$. sapidus: $G=$

Table 3. Cross-correlations between nocturnal flood tide amplitude and the density of crab postlarvae. Correlation coefficients that exceed $95 \%$ confidence limits are shown. The positive correlations at positive lags indicate that postlarvae of most species were abundant 1 to $3 \mathrm{~d}$ after the large amplitude, early evening nocturnal flood tides

\begin{tabular}{|c|c|c|c|c|c|c|c|c|c|}
\hline \multirow{2}{*}{ Taxon } & \multicolumn{9}{|c|}{ Lag (days) } \\
\hline & -4 & -3 & -2 & -1 & 0 & 1 & 2 & 3 & 4 \\
\hline Uca spp. & & & & & & 0.404 & 0.438 & & \\
\hline Panopeus herbstii & & & & & & 0.423 & & & \\
\hline Sesarma reticulatum & & & & & & 0.389 & & & \\
\hline S. cinereum & 0.415 & 0.444 & 0.532 & 0.493 & 0.417 & & & & \\
\hline Eurypanopeus depressus & & & & & & & 0.447 & 0.468 & \\
\hline
\end{tabular}




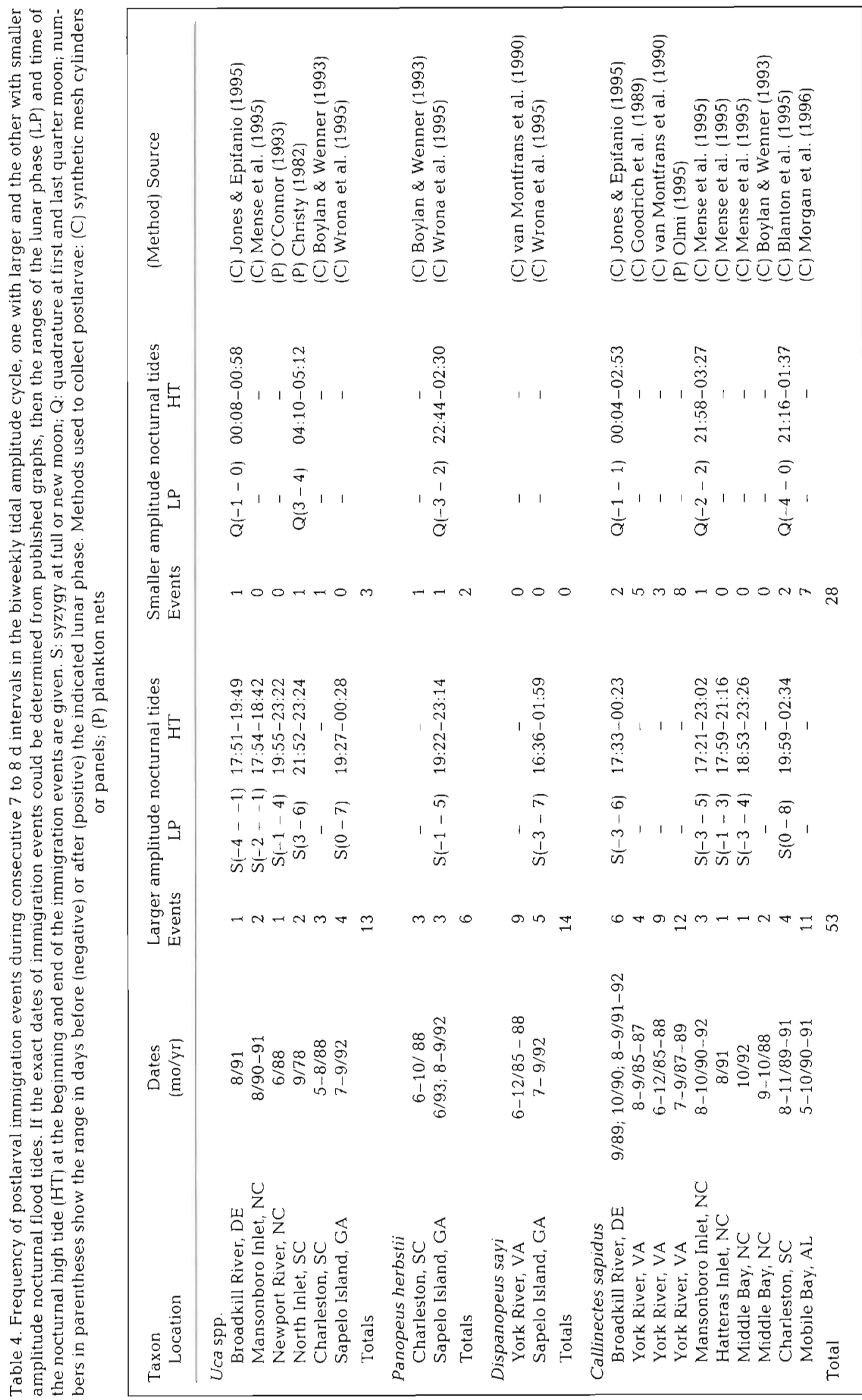


Table 5. Cross-correlations between daily values of crab postlarval density at the lower and mid, mid and upper, and lower and upper sampling stations. Only correlations that exceed their $95 \%$ confidence limits are shown. Positive correlations at positive lags are evidence of progressive, up-estuary movement

\begin{tabular}{|c|c|c|c|c|c|c|c|}
\hline \multirow[t]{2}{*}{ Taxon } & \multirow[t]{2}{*}{ Stations } & \multicolumn{6}{|c|}{ Lag (days) } \\
\hline & & -2 & -1 & 0 & 1 & 2 & 3 \\
\hline Uca spp. & Lower-mid & & & 0.690 & & & \\
\hline & Lower-upper & & & & & 0.614 & \\
\hline Panopeus herbstii & Lower-upper & & & & & 0.619 & \\
\hline Sesarma reticulatum & Lower-mid & & & 0.489 & & & \\
\hline S. cinereum & Lower-mid & & & 0.639 & & & \\
\hline & Mid-upper & & & & & & 0.526 \\
\hline & Lower-upper & & 0.498 & 0.494 & & & \\
\hline Pinnotheres ostreum & Mid-upper & & & 0.596 & & & \\
\hline Eurypanopeus depressus & Lower-upper & 0.587 & 0.478 & & & & \\
\hline
\end{tabular}

7.748, $\mathrm{p}<0.01$, Table 4). This pattern also is evident for Panopeus herbstii, but too few immigration events have been recorded for a statistical test.

\section{Progressive, up-estuary movement}

Three taxa showed progressive, up-estuary movement (Table 5). The pattern is clearest for Uca spp. postlarvae, which were abundant at the lower and mid estuary stations on the same days and at the upper estuary station about $2 \mathrm{~d}$ later. High densities of Panopeus herbstii in the upper estuary also followed high densities at the lower station by $2 \mathrm{~d}$. Sesarma cinereum postlarvae were abundant in the lower and mid estuary on the same day and in the upper estuary $3 \mathrm{~d}$ after they were abundant in the mid estuary. Progressive movement of $S$. reticulatum from the lower to the upper estuary was not detected

\section{DISCUSSION}

\section{General abundance}

The population dynamics and species composition of benthic marine communities can vary substantially due to variation between levels of larval production, settlement and recruitment (reviewed by Caley et al. 1996, Ekman 1996). The planktonic larvae of most estuarine brachyuran crabs may commonly migrate between estuaries and the sea where interspecific differences in their vertical distributions expose them to different currents and causes of mortality (Epifanio 1988, McConaugha 1988, Morgan 1995a, b). Nevertheless, the relative species abundance of immigrating brachyuran postlarvae in the North Inlet estuary was comparable to that of emigrating newly hatched larvae (Christy \& Stancyk 1982). The 7 more abundant taxa of emigrants and immigrants were the same, and $U_{C a}$ spp. larvae and postlarvae were clearly dominant both leaving and entering the estuary. In descending rank order, the next most abundant emigrants were Sesarma cinereum, S. reticulatum and Panopeus herbstii, while the next most abundant immigrants were $P$. herbstii, $S$. reticulatum and $S$. cinereum. Newly hatched larvae were collected on early ebb tides at a single station in the upper estuary (Christy \& Stancyk 1982, Fig. 1) that was up-stream of the large oyster bars in this tidal creek, a preferred $P$. herbstii habitat. Hence, relatively few newly hatched $P$. herbstii larvae would have been in the water ebbing past this station, and this may explain the lower rank of $P$. herbstii in the collections of emigrating larvae compared to immigrating postlarvae.

Little is known about the coastal distribution of crab larvae that emigrate from small to medium sized estuaries. Some may become entrained in eddies around the margins of ebb deltas (Schwing 1981) or in circulation cells in the surf-zone (Lago 1993) and thereby remain close to their estuary of origin. However, estuarine crab larvae often are abundant tens of kilometers from the shore (Dudley \& Judy 1971, Smyth 1980, Truesdale \& Andryszak 1983, Johnson 1985), indicating that extensive dispersal may be common.

The relative species abundances of crab larvae at a given location in the coastal ocean are likely to reflect regional patterns of relative production as well as interspecific differences in transport and survival (Morgan 1995b). The correspondence between the relative abundances of emigrating and immigrating species of crab larvae at North Inlet may therefore indicate substantial between-estuary similarity in crab community species composition in this region 
of the U.S. Atlantic coast, and similar interspecific mortality rates and advective losses. In Flax Pond, a small New York salt marsh, Hovel \& Morgan (1997) found a match between the rank orders of adult abundance of 4 species of estuarine crabs (Uca pugnax, U. pugilator, Sesarma reticulatum, Dyspanopeus sayi) and the abundance of recruiting postlarvae. The results of these 2 studies suggest considerable reliability in levels of recruitment and hence stability in the estuarine crab community in spite of a migratory, planktonic larval phase that is generally thought to uncouple local production from recruitment (Caley et al. 1996).

Although many estuarine crabs exhibit the same temporal pattern of larval production and emigration (Christy \& Stancyk 1982), the extent of their dispersal differs widely (reviewed by Epifanio 1988, McConaugha 1988). The present and Flax Pond studies suggest that larval production and recruitment truly are coupled. If so, then the later larval and postlarval stages of different species may use different, but equally effective mechanisms to return to estuaries for immigration (Shanks 1998) - a process wherein species again converge on a common transport mechanism. Interspecific similarities in dispersal at the endpoints of the larval migratory life of estuarine crabs may reflect the relative predictability of tidal currents in estuaries, and hence their utility for directed transport, as well as the substantial shared benefit of developing in relatively deep, safe water (Morgan \& Christy 1995). Hence, complex adult and larval behaviors may work together to produce predictable and regular recruitment, and 'random processes' in the plankton may little affect the success of crab larval migrations.

\section{Flood-ebb contrasts}

Postlarvae of 6 taxa (at least 9 species) were significantly more abundant in the water column during nocturnal flood than ebb tides (Fig. 3). Considering the crab taxa in North Inlet, this tidal phase abundance asymmetry is well documented elsewhere for Uca spp. (e.g. Little \& Epifanio 1991) and Callinectes sapidus (e.g. Olmi 1994), and it has been reported for Sesarma reticulatum (Hovel \& Morgan 1997), an unspecified xanthid, Pinnixa spp., and Pinnotheres spp. postlarvae (De Vries et al. 1994). This is the first report of the pattern for $S$. cinereum and Panopeus herbstii (identified to species). However, it probably is very general, as the postlarvae of other brachyuran taxa typically are more abundant on flood than ebb tides in estuaries worldwide (e.g. Costa Rica: Dittel \& E.pifanio 1990, South Africa: Lago 1993, Portugal: Queiroga et al. 1994, USA Gulf Coast: Schell 1996).

\section{Light-dark contrasts}

A previous study at North Inlet of immigration of Uca spp. during a lunar moth, showed that postlarvae were about 10 times more abundant in the water column in the upper estuary during nighttime compared to daytime flood tides (Christy 1982). Studies in other estuaries have corroborated this pattern for Uca spp. (e.g. Brookins \& Epifanio 1985, Epifanio et al. 1988, Little \& Epifanio 1991 ) and found it in diverse other taxa as well (e.g. Mense \& Wenner 1989, Dittel \& Epifanio 1990, De Vries et al. 1994, Olmi 1994, Queiroga et al. 1994, Zeng \& Naylor 1996, Hovel \& Morgan 1997, but see Lago 1993).

Our results (Table 2) further support the view that crab postlarvae are primarily nocturnally active in the water column in estuaries, and suggest, additionally, that the light level during a given flood tide has a greater effect on activity than does the tidal amplitude (see also Metcalf et al. 1995). No taxon was more abundant during large amplitude tides that flooded mostly during daylight, and all taxa but Pinnotheres ostreum were more abundant on tides that flooded primarily at night, regardless of their amplitude. Within estuaries, light appears to inhibit expression of tidally phased cycles of swimming activity by brachyuran postlarvae (endogenous in some species, Tankersely \& Forward 1994, Tankersley et al. 1995, Zeng \& Naylor 1996b), even during larger amplitude tides when stimulatory cues, such as changing pressure and salinity, should be stronger (De Vries et al. 1994) and more likely to exceed sensitivity and response thresholds (Tankersley et al. 1995).

\section{Nocturnal flood tide immigration}

Uca spp, Panopeus herbstii, Sesarma reticulatum, and Eurypanopeus depressus postlarvae were most abundant from 1 to $3 \mathrm{~d}$ after the larger amplitude nocturnal flood tides (Fig. 4, Table 3). Since these postlarvae are largely nocturnal, few entered the water column either on the largest amplitude flood tide during daylight or on the larger amplitude semidiurnal tides for which most of the flood occurred before sunset. Hence, they did not maximize their rate of up-estuary movement. As noted previously (Christy 1982), the possible advantages to postlarvae of immigrating rapidly by swimming with the higher velocity flood currents during the larger amplitude tides must be less than the benefits of moving more slowly upstream at night.

Neither Sesarma cinereum nor, especially, Pinnotheres ostreum fit the above pattern. P. ostreum first crabs are not strictly nocturnal and their exceptional dispersal ecology may result from being chemically defended (see below). The correlation between nocturnal 
flood tide amplitude and the abundance of $S$. cinereum appears to have been weak in the first half and strong in the second half of the $32 \mathrm{~d}$ collection period (Fig. 4). Patterns of postlarval abundance within an estuary reflect not only immigration mechanisms, but also variation in the number of postlarvae in the coastal ocean that are available for immigration. Perhaps there were few potential $S$. cinereum immigrants outside the inlet when nocturnal flood tides peaked in mid June.

In other estuaries, immigration (usually measured indirectly as settlement) by Uca spp., Dyspanopeus sayi, Callinectes sapidus and Panopeus herbstii tends to occur during the half of the biweekly tidal amplitude cycle with larger amplitude nocturnal flood tides (Table 4). Hence, the pattern at North Inlet appears to be general. Immigration during relatively low amplitude nocturnal flood tides is, however, not unusual. For example, about $35 \%$ of the immigration events scored for $C$. sapidus occurred under such conditions. It seems unlikely that postlarvae directly select tidal amplitude conditions for immigration. Although mechanisms that could concentrate postlarvae near shore approximately every 2 weeks have been proposed (Pineda 1991, Shanks 1995), it is not yet clear whether postlarval abundance in the pool of potential immigrants typically varies as these mechanisms predict (Shanks 1998). The trend toward immigration and settlement during larger amplitude nocturnal tides may simply reflect the effects of the changing phase relationships between the tidal, light and tidal amplitude cycles on the expression of nocturnal flood tide swimming by postlarvae (Table 2).

The lunar phase associated with the larger amplitude biweekly nocturnal flood tides varies, especially on coasts with diurnal or mixed semidiurnal tidal patterns (e.g. Morgan et al. 1996). Even on coasts with semidiurnal tides, the time between successive larger amplitude nocturnal tides ranges from about 12 to $17 \mathrm{~d}$. (e.g. Fig. 2). Furthermore, at temperate latitudes, seasonally changing day length causes seasonal variation in the day of the semilunar cycle on which the largest amplitude nocturnal tide occurs. We suggest that the nocturnal flood tide amplitude cycle, not the lunar, semilunar or even semidiurnal tidal amplitude cycles is the appropriate physical cycle for examining temporal variation in crab postlarval immigration to estuaries (see also Olmi 1995).

\section{Why are postlarvae nocturnal?}

The adaptive significance of nocturnal activity by brachyuran postlarvae in estuaries has received little comment (Olmi 1994, Hovel \& Morgan 1997). There is considerable support for the hypothesis that predation, primarily by daytime-active planktivorous fish, selects for larval release on large amplitude, nocturnal ebb tides; such timing promotes rapid nocturnal emigration of newly hatched crab larvae from shallow estuarine and coastal waters where planktivorous fish are most abundant to safer, offshore locations (Morgan 1990. Morgan \& Christy 1995). The larvae of species that are released in daylight (Christy 1986, Morgan \& Christy $1996 \mathrm{a}$ ) or that do not typically migrate between estuaries and the ocean (Cronin \& Forward 1982) have spines or cryptic colors that make them less vulnerable to predation than are larvae that emigrate (Christy 1982, 1986, Morgan 1987, 1990, Morgan \& Christy 1996a). When crab postlarvae return to estuaries they may encounter high densities of the planktivorous fishes they escaped when they emigrated.

In the North Inlet estuary, Johnson et al. (1990) found that the bay anchovy Anchoa mitchilli, a common planktivore in temperate western Atlantic estuaries, strongly preferred crab postlarvae (mostly Uca spp., Johnson et al. 1990) which constituted up to $60 \%$ of the fishes' diet. As is generally true of planktivorous fish (Hobson \& Chess 1978, Zaret 1980, Lazzaro 1987), A. mitchilli fed more during the day than at night. Hence crab postlarvae may reduce their risk of predation by being active in the water column at night. Indeed, the percentage contribution of postlarvae to the diet of $A$. mitchilli dropped from $42 \%$ during the day to $31 \%$ at night, even though the concentration of postlarvae in the water column should have been considerably greater at night. Pinnotheres ostreum postlarvae (first stage swimming crabs) were exceptional among the species we studied as they were not primarily nocturnal. They also were not eaten by $A$. mitchilli in North Inlet even when abundant (Johnson et al. 1990). Stage 4 crabs (also a swimming stage) of $P$. ostreum are unpalatable to 4 other estuarine planktivorous fishes, perhaps because they are chemically defended (Luckenbach \& Orth 1990). Just as welldefended crab zoeae do not emigrate rapidly from shallow waters on nocturnal ebb tides (as a consequence of both the timing of larval release and larval behavior), so too may well-defended postlarvae fail to immigrate primarily on nocturnd flood tides. Hence, predictable spatial and temporal gradients of predation by fish on crab larvae and postlarvae that vary interspecifically in their vulnerability to these predators may explain interspecific differences in associations between the timing of larval release and the timing and extent of larval and postlarval migrations.

\section{Saltatory, up-estuary immigration}

Though small, North Inlet is not atypical of estuaries on the middle to lower U.S. Atlantic coast. Even though 
the lower and upper sampling stations were separated by only about $4 \mathrm{~km}$, we found evidence of saltatory up-estuary immigration over 1 to 2 nights by Uca spp. postlarvae and an indication of this pattern in Panopeus herbstii and Sesarma cinereum. This pattern should be more pronounced in larger estuaries.

There is considerable evidence that the postlarvae selectively swim up in the water column during nocturnal flood tides, which could result in progressive, up-estuary immigration on successive nights (saltatory transport) to adult habitats. This is the first study that documents this pattern directly by sampling, on the appropriate spatial and temporal scales, the density of postlarvae in the water column. Consequently, variation in the spatial patterns and rates of immigration within and between estuaries is poorly known. However, a long-term settlement study of Callinectes sapidus postlarvae in Mobile Bay (Morgan et al. 1996) suggests that immigration rates vary greatly between species and locations. Although onshore winds enhanced transport of blue crab postlarvae to the mouth of Mobile Bay, once in the estuary, tidal transport best explained settlement patterns (see also Olmi 1995). Postlarvae settled $50 \mathrm{~km}$ up-stream about 2 to $3 \mathrm{~d}$ after they settled near the bay mouth (Morgan et al. 1996). If daily variation in settlement is correlated with daily variation in the concentration of postlarvae in the water column (Lipcius et al, 1990, but see Olmi et al. 1990), then, in Mobile Bay, C. sapidus moved up-estuary at roughly 15 to $20 \mathrm{~km} \mathrm{~d}^{-1}$, compared to the rate of 2 to $4 \mathrm{~km} \mathrm{~d}^{-1}$ by $U$ ca spp. postlarvae in the North Inlet estuary. Although the behavioral mechanisms that regulate vertical migration by postlarvae of these 2 taxa in estuaries differ (DeVries et al. 1994, Tankersley \& Forward 1994, Tankersley et al. 1995), both taxa immigrate predominantly on nocturnal flood tides. Larger $C$. sapidus postlarvae swim substantially faster than Uca spp. postlarvae (Luckenbach \& Orth 1992, but see Nosler cited in Feest 1969) and the predominantly diurnal tidal pattern in Mobile Bay provides $12 \mathrm{~h}$ of flood directed transport daily compared to only $6 \mathrm{~h} \mathrm{~d}^{-1}$ in North Inlet. However, flood tide current velocities in the relatively narrow channels in North Inlet are substantially greater than flood current velocities in open, shallow, Mobile Bay waters. Hence, we can not adequately explain the 5-to 10-fold difference in immigration rate by these 2 taxa in these very different estuarine systems and tidal regimes.

Synthetic fiber collectors are widely used to monitor settlement of estuarine crab postlarvae. Daily counts of the number of postlarvae that cling to these collectors probably yield reasonably accurate estimates of seasonal, monthly and even biweekly (O'Connor 1993) levels of immigration. However, saltatory, up-estuary immigration by postlarvae may be rapid, and counts of postlarvae on collectors sometimes are (Lipcius et al. 1990) and sometimes are not (Olmi et al. 1990) closely correlated with day-to-day variation in the concentration of postlarvae in the water column. Given substantial and poorly understood variation in the relationship between the concentration of immigrants in the water column and levels of settlement, it may be best to study immigration directly by sampling the plankton daily during nocturnal flood tides at stations from the lower to upper estuary, as was done in this study. Accurate descriptions of the dynamics of the horizontal migratory movements of postlarvae in estuaries are essential for understanding how recruitment is affected by tidal currents, developmental competency, settlement behavior, the distribution of adult habitats and predation.

Acknowledgements. J.H.C. thanks F. John Vernberg, Dennis Allen and the staff of the Belle W. Baruch Institute for Marine Biology and Coastal Research for their generous support and capable assistance. This research was funded by the National Science Foundation (Grant OCE 77-20690 to J.H.C.), with additional support from the Smithsonian Tropical Research Institute and a Smithsonian Institution Postdoctoral Fellowship (to S.G.M.). Contribution number 1162 of the Belle W. Baruch Institute for Marine Biology and Coastal Research, University of South Carolina

\section{LITERATURE CITED}

Barnwell FH (1976) Variation in the form of the tide and some problems it poses for biological timing systems. In: DeCoursey PJ (ed) Biological rhythms in the marine environment. University of South Carolina Press, Columbia, p $161-187$

Blanton JE, Wenner F, Knott D (1995) Effects of wind-generated coastal currents on the transport of blue crab megalopae on a shallow continental shelf. Bull Mar Sci 57: $739-752$

Boylan JM, Wenner EL (1993) Settlement of brachyuran megalopae in a South Carolina, USA, estuary. Mar Ecol Prog Ser 97:237-246

Brookins KG, Epifanio CE (1985) Abundance of brachyuran larvae in a small coastal inlet over six consecutive tidal cycles. Estuaries 8:60-67

Caley MJ, Carr MH, Hixon MA, Hughes TP, Jones GP, Menge BA (1996) Recruitment and the local dynamics of open marine populations. Annu Rev Ecol Syst 27:477-500

Christensen AM, McDermott JJ (1958) Life-history and biology of the oyster crab Pinnotheres ostreum Say. Biol Bull $114: 146-179$

Christy JH (1982) Adaptive significance of semilunar cycles of larval release in fiddler crabs (genus Uca) test of an hypothesis. Biol Bull 163:251-263

Christy JH (1986) Timing of larval release by intertidal crabs on an exposed shore. Bull Mar Sci 39:176-191

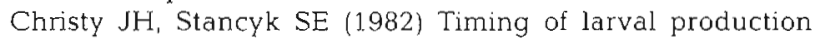
and flux of invertebrate larvae in a well-mixed estuary. In: Kennedy $V$ (ed) Estuarine comparisons. Academic Press, New York, p 489-503

Costlow JD, Bookhout CG (1962) The larval development of Sesarma reticulatum Say reared in the laboratory. Crustaceana 4:281-294 
Cronin TW (1982) Estuarine retention of larvae of the crab Rhithropanopeus harrisij. Estuar Coast Shelf Sci 15: $207-220$

Cronin TW, Forward RB Jr (1982) Tidally timed behavior: effects on larval distributions in estuaries. In: Kennedy VS (ed) Estuarine comparisons. Academic Press, New York, p 505-520

DeVries MC, Tankersley RA, Forward RB Jr, Kirby-Smith WW, Luettich RA Jr (1994) Abundance of estuarine crab larvae is associated with tidal hydrologic variables. Mar Biol 118:403-413

Dittel AR, Epifanio CE (1990) Seasonal and tidal abundance of crab larvae in a tropical mangrove system, Gulf of Nicoya, Costa Rica. Mar Ecol Prog Ser 65:25-34

Dittel AR, Epifanıo CE, Lizano O (1991) Flux of crab larvae in a mangrove creek in the Gulf of Nicoya, Costa Rica. Estuar Coast Shelf Sci 32:129-140

Dudley DL, Judy MH (1971) Occurrence of larval, juvenile and mature crabs in the vicinity of Beaufort Inlet. North Carolina. Technical Report, NMFS, Special Scientific Report, Fisheries 673:1-10

Eckman JE (1996) Closing the larval loop: linking larval ecology to the population dynamics of marine benthic invertebrates. J Exp Mar Biol Ecol 200:207-237

Epifanio CE (1988) Transport of invertebrate larvae between estuaries and the continental shelf. Am Fish Soc Symp 3: $104-114$

Epifanio CE, Little KT, Rowe PM (1988) Dispersal and recruitment of fiddler crab larvae in the Delaware River estuary. Mar Ecol Prog Ser 43:181-188

Epifanio CE, Valenti CC, Pembroke AE (1984) Dispersal and recruitment of blue crab larvae in Delaware Bay, USA. Estuar Coast Shelf Sci 18:1-12

Feest J (1969) Morphophysiological studies on the ontogeny and sexual biology of Uca annulipes and Uca triangularis as compared to Ilyoplax gangetica. Forma Functio 1 : $159-225$

Gaines SD, Bertness MD (1992) Dispersal of juveniles and variable recruitment in sessile marine species. Nature 360 $579-580$

Garvine RW, Epifanio CE, Epifanio CC, Wong KC (1997) Transport and recruitment of blue crab larvae: a model with advection and mortality. Estuar Coast Shelf Sci 45: $99-111$

Goodrich DM, van Montfrans J, Orth RJ (1989) Blue crab megalopal influx to Chesapeake Bay: evidence for a winddriven mechanism. Estuar Coast Shelf Sci 29:247-260

Grove MW, Woodin SA (1996) Conspecific recognition and host choice in a pea crab, Pinnixa chaetopterana (Brachyura: Pinnotheridae). Biol Bull 190:359-366

Hobson ES, Chess JR (1978) Trophic relationships among fishes and plankton in the lagoon at Enewetok Atoll, Marshall Islands. Fish Bull 76:133-153

Hovel K, Morgan SG (1997) Planktivory as a selective force for reproductive synchrony and larval dispersal. Mar Ecol Prog Ser 157:79-95

Johnson DF (1985) The distribution of brachyuran crustacean megalopae in the waters of the York River, lower Chesapeake Bay and adjacent shelf: implications for recruitment. Estuar Coast Shelf Sci 20:693-705

Johnson DR, Hester BS (1989) Larval Transport and its association. with recruitment of blue crabs to Chesapeake Bay. Estuar Coast Shelf Sci 28:459-472

Johnson WS, Allen DA, Ogburn MV, Stancyk SE (1990) Shortterm predation responses of adult bay anchovies Anchoa mitchilli to estuarine zooplankton availability. Mar Ecol Prog Ser 64:55-68
Jones MB, Epifanio CE (1995) Settlement of brachyuran megalopae in Delaware Bay: and analysis of time series data. Mar Ecol Prog Ser 125:67-76

Kjerfve BJ (1978) Bathymetry as an indicator of net circulation in well mixed estuaries. Limnol Oceanogr 23:816-821

Kjerfve BJ, Proehl JA (1979) Velocity variability in a crosssection of a well-mixed estuary. J Mar Res 37:409-418

Kjerfve B, Proehl JA, Schwing FB, Seim HE, Marozas M (1982) Temporal and spatial considerations in measuring estuarine water fluxes. In: Kennedy VS (ed) Estuarine comparisons. Academic Press, New York, p 37-51

Kjerfve BJ, Wolaver TG (1988) Sampling optimization for studies of tidal transport in estuaries. Am Fish Soc Symp 3: $26-33$

Lago RP (1993) Tidal exchange of larvae of Sesarma catenata (Decapoda, Brachyura) in the Swartkops estuary, South Africa. S Afr J Zool 28:182-191

Lambert R, Epifanio CE (1982) A comparison of dispersal strategies in 2 genera of brachyuran crab in a secondary estuary. Estuaries 5:182-188

Lazzaro X (1987) A review of planktivorous fishes: their evolution, feeding behaviors, selectivities and impacts. Hydrobiologia 146:97-167

Lipcius RN, Olmi EJ III, van Montfrans J (1990) Planktonic availability, molt stage and settlement of blue crab postlarvae. Mar Ecol Prog Ser 58:235-242

Little KT, Epifanio CE (1991) Mechanism for the re-invasion of an estuary by 2 species of brachyuran megalopae. Mar Ecol Prog Ser 68:235-242

Luckenbach MW, Orth RJ (1990) A chemical defense in Crustacea? J Exp Mar Biol Ecol 137:79-87

Luckenbach MW, Orth RJ (1992) Swimming velocities and behavior of blue crab (Callinectes sapidus Rathbun) megalopae in still and flowing water. Estuaries 15: $186-192$

McConaugha JR (1988) Export and reinvasion of larvae as regulators of estuarine dependent decapod populations. Am Fish Soc Symp 3:90-103

Mense DJ, Posey MH, West T, Kincheloe K (1995) Settlement of brachyuran postlarvae along the North Carolina Coast. Bull Mar Sci 57:793-806

Mense DJ, Wenner EL (1989) Distribution and abundance of early life history stages of the blue crab. Callinectes sapidus, in tidal marsh creeks near Charleston, South Carolina. Estuaries 12:157-168

Metcalf KS, Lipcius RN (1992) Relationship of habitat and spatial scale with physiological state and settlement of the blue crab postlarvae in Chesapeake Bay. Mar Ecol Prog Ser 82:143-150

Metcalf KS, van Montfrans J, Lipcius RN, Orth RJ (1995) Settlement indices for blue crab megalopae in the York River, Virginia: temporal relationships and statistical efficiency. Bull Mar Sci 57:781-792

Morgan SG (1987) Morphological and behavioral antipredatory adaptations of decapod zoeae. Oecologia 73:393-400

Morgan SG (1989) Adaptive significance of spination in estuarine crab zoeae. Ecology 70:462-482

Morgan SG (1990) Impact of planktivorous fishes on dispersal, hatching and morphology of estuarine crab larvae. Ecology 71:1639-1652

Morgan SG (1995a) The timing of larval release. In: McEdward L (ed) Ecology of marine invertebrate larvae. CRC Press, Boca Raton, p 157-191

Morgan SG (1995b) Life and death in the plankton: larval mortality and adaptation. In: McEdward L (ed) Ecology of marine invertebrate larvae. CRC Press, Boca Raton, p 279-322 
Morgan SG, Christy JH (1994) Plasticity, constraint, and optimality in reproductive timing. Ecology 75:2185-2203

Morgan SG, Christy JH (1995) Adaptive significance of the timing of larval release by crabs. Am Nat 145:457-479

Morgan SG, Christy JH (1996a) Planktivorous fishes as selective agents for reproductive synchrony. J Exp Mar Biol Ecol 209:89-101

Morgan SG, Christy JH (1996b) Survival of marine larvae under countervailing selective pressures of photodamage and predation. Limnol Oceanogr 41:498-504

Morgan SG, Zimmer-Faust RK, Heck KL Jr, Coen LD (1996) Population regulation of blue crabs Callinectes sapidus in the northern Gulf of Mexico: postlarval supply. Mar Ecol Prog Ser 133:73-88

O'Connor NJ (1993) Settlement and recruitment of the fiddler crabs Uca pugnax and Uca pugilator in a North Carolina, USA, salt marsh. Mar Ecol Prog Ser 93:227-234

Olmi EJ II (1994) Vertical migration of blue crab (Callinectes sapidus) megalopae: implications for transport in estuaries. Mar Ecol Prog Ser 113:39-54

Olmi EJ III (1995) Ingress of blue crab megalopae in the York River, Virginia, 1987-1989. Bull Mar Sci 57:753-780

Olmi EJ III, van Montfrans J, Lipcius RN, Orth RJ, Sadler P (1990) Variation in planktonic availability and settlement of blue crab megalopae in the York River, Virginia. Bull Mar Sci 46:230-243

Palmer MA, Kjerfve BJ, Schwing FB (1980) Tidal analysis and prediction in a South Carolina estuary. Contrib Mar Sci 23: $17-23$

Pethick JS (1980) Velocity surges and asymmetry in tidal channels Estuar Coast Mar Sci 11:331-345

Pineda J (1991) Predictable upwelling and the shoreward transport of planktonic larvae by internal tidal bores. Science 253:548-551

Provenzano AJ, McConaugha JR, Phillips KB, Johnson DJ, Clark J (1983) Vertical distribution of first stage larvae of the blue crab, Callinectes sapidus, at the mouth of Chesapeake Bay. Estuar Coast Shelf Sci 16:489-499

Queiroga H, Costlow JD, Moreira MH (1994) Larval abundance patterns of Carcinus maenas (Decapoda, Brachyura) in Canal de Mira (Ria de Aveiro, Portugal). Mar Ecol Prog Ser 111:63-72

Salmon M, Seiple WH, Morgan SG (1986) Hatching rhythms of fiddler crabs and associated species at Beaufort, North Carolina. J Crust Biol 6:24-36

Sandifer PA (1973) Distribution and abundance of decapod crustacean larvae in the York River estuary and adjacent lower Chesapeake Bay, Virginia, 1968-1969. Chesapeake Sci 14:235-257

Sandifer PA (1975) The role of pelagic larvae in recruitment to populations of adult decapod crustaceans in the York River estuary and adjacent lower Chesapeake Bay, Virginia. Estuar Coast Mar Sci 3:269-279

Schell JM (1996) Variation in the timing of vertical swimming by crab larvae and megalopae in a diurnal tidal regime. MS thesis, State University of New York at Stony Brook

Editorial responsibility: Jospeh Pawlik (Contributing Editor), Wilmington, North Carolina, USA
Schwing FB (1981) Conceptual model for entrainment of larvae in a well mixed estuary. MS thesis, University of South Carolina, Columbia

Shanks AL (1995) Mechanisms of cross-shelf dispersal of larval invertebrates and fish. In: McEdward L (ed) Ecology of marine invertebrate larvae. CRC Press, Boca Raton, p 323-367

Shanks AL (1998) Abundance of post-larval Callinectes sapidus, Penaeus spp., Uca spp., and Libinia spp. collected at an outer coastal site and their cross-shelf transport. Mar Ecol Prog Ser 168:57-69

Smyth PO (1980) Callinectes (Decapoda: Portunidae) larvae in the middle Atlantic bight, 1975-1977. Fish Bull 78: $251-265$

Sokal RR, Rohlf FJ (1981) Biometry. Freeman, San Francisco

Stancyk SE, Feller RJ (1986) Transport of non-decapod invertebrate larvae in estuaries: an overview. Bull Mar Sci 39: $257-268$

Strathmann RR (1982) Selection for retention or export of larvae in estuaries. In: Kennedy VS (ed) Estuarine comparisons. Academic Press, New York, p 521-536

Sulkin SD (1984) Behavioral basis of depth regulation in the larvae of brachyuran crabs. Mar Ecol Prog Ser 15: 181-205

Tankersley RA, Forward RB Jr (1994) Endogenous swimming rhythms in estuarine crab megalopae: implications for flood-tide transport. Mar Biol 118:415-423

Tankersley RA, Mckelvey LM, Forward RB Jr (1995) Responses of estuarine crab megalopae to pressure, salinity and light: implications for flood-tide transport. Mar Biol 122:391-400

Truesdale FM, Andryszak BL (1983) Occurrence and distribution of reptant decapod crustacean larvae in neritic Louisiana waters: July 1976. Contrib Mar Sci 26:37-53

van Montfrans J, Epifanio CE. Knott DM, Lipcius RN, Mense DJ, Metcalf KS, Olmi EJ III, Orth RJ, Posey MH, Wenner EL, West TL (1995) Settlement of blue crab postlarvae in western north Atlantic estuaries. Bull Mar Sci 57:834-854

van Montfrans J, Perry CA, Orth RJ (1990) Daily, monthly and annual settlement patterns by Callinectes sapidus and Neopanope sayi megalopae on artificial collectors deployed in the York River, Virginia: 1985-1988. Bull Mar Sci 46:214-229

Wrona AB, Wiegert RG, Bishop TD (1995) Initial report of setthement patterns of brachyuran megalopae at Sapelo Island, Georgia, USA. Bull Mar Sci 57:807-820

Zaret TM (1980) Predation and freshwater communities. Yale University Press, New Haven

Zeng C, Naylor E (1996a) Endogenous tidal rhythms of vertical migration in field collected zoeae-1 larvae of the shore crab Carcinus maenas: implications for ebb tide offshore dispersal. Mar Ecol Prog Ser 132:71-82

Zeng C, Naylor E (1996b) Occurrence in coastal waters and endogenous tidal swimming rhythms of late megalopae of the shore crab Carcinus maenas: implications for inshore recruitment. Mar Ecol Prog Ser 136:69-79

Submitted: March 23, 1998; Accepted: August 3, 1998

Proofs received from author(s): October 30, 1998 